\title{
Ponzi Schemes: An Analysis on Coping with Economic Recession in Nigeria
}

\author{
Jackson T.C.B. Jack ${ }^{1}$ \\ Christopher Chimaobi Ibekwe ${ }^{2}$ \\ Department of Sociology \& Anthropology ${ }^{1}$ \\ Federal University Otuoke, Bayelsa State, Nigeria \\ Department of Sociology/Anthropology ${ }^{2}$ \\ Nnamdi Azikiwe University, Awka, Nigeria
}

DOI:10.36108/NJSA/8102/61(0150)

\begin{abstract}
The proliferation of Ponzi schemes in Nigeria appear to coincide with the official declaration of economic recession in early 2016. It is therefore pertinent to empirically investigate the nexus between the recession and Ponzi schemes in the country. Anchored theoretically on Robert Merton's Strain Theory the study was guided by two research objectives and one hypothesis. The snow-balling sampling technique was used to select 135 Ponzi scheme participants from Rivers, Bayelsa and Anambra States. Descriptive analysis of the results was undertaken in tables, charts and graphs. The findings revealed amongst others that MMM, Ultimate cycler, Givers Forum, Get Help World Wide were the major Ponzi schemes in Nigeria. It was also found that Ponzi schemes are a coping strategy for economic recession. The paper posits that until the economic downturn is adequately addressed and the economy revamped, Ponzi schemes would continue to thrive in Nigeria. It recommended economic revitalisation through effective economic diversification policies that will enhance provision of socio-economic livelihood as palliatives to recession induced strain.
\end{abstract}

Keywords: Coping strategy, economic recession, ponzi schemes, scam, victims

\section{Introduction}

The get-rich-quick syndrome and obsession for easy money which forms part of the dominant socio-cultural values in contemporary Nigeria have continued to plunge many into various forms of coping strategies in the face of harsh economic realities. Recently, the Central Bank of Nigeria (2015) and International Monetary Fund (2016) clearly stated that Nigeria's economy has slipped into recession. This is evident in negative economic growth rates and significant decline in economic activities in the country, resulting in increased hardship, rising unemployment, low output, falls in availability of credit, illiquidity and rising inflationary pressures. Hence, the need for Nigerians to device strategies to cope with these economic realities becomes pertinent.

Since early 2016 when the country's economy was officially declared to have lurched into a recession there has been an upsurge in the proliferation of financial Ponzi schemes amongst Nigerians. Perhaps, this is suggestive of the fact that Ponzi schemes may be a palliative to cushion the effects of the recession (NOIPolls, 2017). According to Onyeji (2016), different unorthodox 
financial schemes mostly Mavrodi Mundial Movement (MMM), Ultimate Cycler, Zar Fund, Givers Forum, I-charity, Crowd Rising, Get Help Worldwide, Claritta, Twinkas and so on have continually gained patronage across Nigeria since the recession. Unarguably, most of these schemes especially MMM had earlier existed and collapsed in countries like China, South Africa, Zimbabwe and several other places leading to loss of money by millions of people, not forgetting the associated psychological trauma (Elezuo, 2016; Mphambela, 2017).

Across cultures, various forms of Ponzi schemes exist which are being patronized by desperate money seekers, oblivious of certain inherent dangers. In the U.S.A for example, Ponzi scheme investigations accounts for about $21 \%$ of the Security and Exchange Commission's (SEC's) enforcement workload in 2010 alone, compared with $17 \%$ in 2008 and 9\% in 2005 (Johnston, Johnson \& Hummel, 2010). According to Blanton (2012), a notable Ponzi in the U.S, named the 'Problem Solver' targets individuals in financial distress who feel they are down on their luck with increasing debt crises and have nowhere to turn for help. He also noted that 'Debt Resolution' scams were common during the economic recession with failed outcomes as well as ruined credit ratings for customers.

As the economic recession lingers in Nigeria, the financial community continues to learn about many Ponzi schemes and other frauds that have proliferated during the period. The consequences are however numerous and many are prone to them as they struggle to eke out a living in the face of unfavourable economic realities. It is in light of the foregoing that this paper investigates the nexus between the economic recession and proliferation of Ponzi schemes in Nigeria. Specifically, the paper seeks to:

(i) Identify and examine the major Ponzi schemes in Nigeria.

(ii) Ascertain if investments in Ponzi schemes is a coping strategy to economic recession.

\section{Conceptual Clarification}

The following concepts which are used in the paper are operationalized for proper understanding and clarification:

Ponzi Schemes: These are fraudulent investments where earlier investors' returns are paid from the contributions of later investors (Wilkins, Acuff \& Hermanson, 2012). To Greenspan (2011), it is a fraud where invested money is pocketed by the schemer and investors who wish to redeem their money are actually paid out of proceeds from new investors. It is also an investment where the fund originator never made a legitimate investment in assets that produce income (Deason, Rajgopal, Waymire \& White, 2015). According to Sadiraj and Schram (2000), Ponzi schemes are fraudulent games where individuals or companies pay out interest returns to some invested parties by borrowing funds from others. From the foregoing therefore, Ponzi schemes can be described as an enticing established swindle networking where money of 
newer entrants or investors are used to pay increased returns to earlier investors rather from profit earned through legitimate business investment.

Historically, Ponzi schemes are not new, but have been in operation since the mid 1800's. Ponzis were rather popularized in the early 1900's by the mastermind fraudster - Charles Ponzi (March 3rd, 1882 - January 18th, 1949). He announced an arbitrage business of buying postal reply coupons in Italy and exchanges them for stamps in the U.S.A. He attracted investors by promising extraordinarily high returns of $50 \%$ in 45 days (Stelter, Berger, Odewald \& Schilder, 2013). They noted that instead of investing the money to buy the coupons and exchange them for stamps, he simply used the money of later investors to pay returns to earlier investors, extracting huge profits along the way and when it collapsed over $\$ 20$ million which was estimated to be equivalent of $\$ 225$ million as at 2011 was lost. Since then, the world has been littered with distinct versions of such schemes; little wonder Ponzis are referred to as the grand-daddy of all financial frauds (Quisenberry, 2017; Rodney, 2010).

Ponzi schemes have been categorized as a 'white collar crime'. The term 'white collar crime' was first coined by Edwin Sutherland in 1940, as a crime committed by a person of respectability and high social status in the course of his occupation (Sutherland cf. Sher, 2015). Therefore, Ponzi schemes are forms of non-violent crime which is usually initiated and coordinated by influential individuals who are classified as intelligent, popular and initially well respected in their respective line of work. Example is the recent conviction of Bernard Madoff, a highly-regarded Hedge Fund Manager and a former president of the National Association of Securities Dealers Automated Quotations (NASDAQ) for running a very sophisticated Ponzi scheme which defrauded over 50 billion dollars (Greenspan, 2011). Ponzi schemers always seek to recruit new investors and so long as new investments are expanding at a healthy rate, the schemer keeps the fraud going. To Deason, Rajgopal, Waymire, White (2015), the survival of a Ponzi scheme depends on the schemer's ability to keep attracting new investors who make sufficiently large contributions to sustain high payouts to existing investors.

Operators of Ponzi schemes usually entice new investors by offering higher returns than other investments in form of short-term returns that are either abnormally high or unusually consistent. Initially, the promoter will pay out high returns to attract or lure more investors into putting additional money. The return to the initial investors is paid out of the investments of new entrants, rather than solely from profits. Ponzi schemers' descriptions of their investment strategy range from investing in stocks and bonds to real estate transactions, international trade and so forth (Deason et al., 2015). Generally, all Ponzi schemes have but not limited to the following characteristics:

i. Offering of abnormal higher returns on investment.

ii. Desperate search for new investors that will sustain the scheme. 
iii. Pay 'investment returns' out of the new investments made by newer entrants and not out of profits of a legitimate business venture (i.e. collecting from Mr. C to pay Mr. A).

iv. Continuously update investors on their accumulating interest or capital gains update to keep them relaxed.

v. Spread of testimonies of people that have benefited through social media or those around someone.

vi. Advocate for continuous re-investment to sustain the live-wire of the scheme.

vii. Message of helping people or empowerment without traceable source of income.

viii. More investors introduced more referral bonuses accruing.

ix. Matched with another member to provide help $(\mathrm{PH})$ or get help $(\mathrm{GH})$, etc.

Economic Recession: This simply refers to a general downturn in economic activities of a country. The National Bureau of Economic Research (NBER, 2007) defines economic recession as a significant decline in economic activity spread across the economy and lasting for more than a few months, usually seen in economic indicators such as Gross Domestic Product (GDP), real income, employment, industrial production and wholesale-retail sales. It is characterized by rising cost of production, fall in investment, employment, income and demand as well as a fall in firms profitability accompanied by distress in the stock market and banking system. Generally, recession occurs when there is a widespread decline in aggregate expenditure by government, households and firms, which is triggered by international trade imbalances, financial crisis, negative supply shock, and more.

More so, a recession is commonly accompanied by a decline in the GDP (a major indicator of economic recession which measures the overall performance of an economy) for two or more consecutive quarters. The International Monetary Fund (2016), reports that Nigeria's real GDP growth declined tremendously from $2.7 \%$ in 2015 to $-1.7 \%$ in 2016 , thereby suggesting a negative growth rate (Noko, 2016). This situation portends grave consequences for the economy as the nation continues to swim in the deep waters of recession.

One of such consequences is an increase in the level of unemployment as firms lay off employees in a bid to cut cost and resolve the crises of profitability. According to Onuchuku (2016), the average rate of unemployment was $18.19 \%$ between 2011 and 2015. The progressive deterioration in the unemployment rate of the country reached a dismal level in 2016 (the recession year) when the Nigerian Bureau of Statistics reported that Nigeria's unemployment rate rose from $13.3 \%$ in the second quarter of 2016 to $13.9 \%$ in the third quarter of same year (NBS, 2016). The economic recession was indicted for this increase in unemployment rate. Aside unemployment, the recession has impacted negatively on household consumption patterns in the 
country. The National Bureau of Statistics reports a decline in household consumption demand from $-0.7 \%$ to $-2.0 \%$ in the third quarter of 2016 . This in turn precipitates contraction in business cycle and causes supply shock which triggers inflationary pressure in the economy. Consequently, the NBS (2016) noted increase in inflation by the rate of $17.9 \%$. Therefore, the impact of recession on the Nigerian economy cannot be overemphasized as it portends multi-faceted socio-economic problems for the country.

Coping Strategy: According to Folkman, Lazarus, Dunkel-Schetter, Delongis and Gruen (1986: 993), "coping is a person's constantly changing cognitive and behavioral efforts to manage specific external and/or internal demands that are appraised as taxing or exceeding the person's resources". From their perspective, 'coping' has two primary functions which are to regulate stressful emotions and to alter the troubled person-environment relationship that causes distress. Similarly, Wisener, Blaikie, Cannon and Davis (2004: 113-115) defines coping as a way to act and manage resources in unusual, abnormal and adverse situations. To Wisener et al (2004), the use of resources here implies physical and social manners to gain livelihood and ability to access safety. From the foregoing therefore, coping strategy refers to the specific efforts, either behavioural or psychological that people employ to master, tolerate, reduce or minimize stressful events such as a natural disaster or as in this case, an economic recession.

In the light of the above, within the context of this study as the Nigerian economy is beset with myriads of economic problems ranging from unemployment to bad leadership and structure of governance that has climaxed into economic recession; Ponzis schemes according to Asogwa, Etim, Etukafia, Akpanuko and Ntiedo (2017) became a coping alternative to the harsh economic realities in the country. They submit that the presently constituted economy is not viable and as hunger, poverty and unemployment continue to rake the nation, people seek alternative means to cushion the effects. Similarly, a study conducted by Bupo and Abam-Smith (2017), which investigated the perception of business education students in Rivers State University, Port Harcourt revealed that the respondents agreed that Ponzi schemes legitimately increased their income and reduces the impact of recession on them. They agreed that Ponzi schemes are scams that will surely crash, but that the durability is based on the continued joining of more people. This implies that despite knowing the implications, many involve in Ponzi schemes as a strategy of cushioning the effects of harsh economic realities.

\section{Theoretical Framework}

This paper is anchored on the theoretical assumptions of the strain theory as propounded by American sociologist, Robert K. Merton in his work "Social Structure and Anomie" (1938). The theory explains deviant behaviour and crime as inevitable outcome of the strain individuals experience when society 
does not provide adequate and approved means to achieve culturally valued goals. It holds that society puts pressure on individuals to achieve socially accepted goals (e.g. financial security), but often they lack the approved means in actualizing such goals. This situation is what Merton referred to as structural strain i.e. the discrepancy between culturally defined goals and the institutionalized means available to achieve these goals.

Structural strain can lead to individual strain which is the frictions and pains experienced by many unprivileged individuals as they search for ways to satisfy their needs. Strain therefore occurs when there is a gap between an individual's goals and their current status which may lead the individual to seek out for dishonest or illegitimate means in meeting those needs such as engaging in criminal activities. This implies that when the socially acceptable goals appear to be more significant to individuals, the need to achieve them may become more important than the approved means of hard work, discipline and even determination. In such cases, the prevailing norm would be 'the end justifies the means' as individuals become resolute on achieving their goals by 'hook or crook'.

However, the strain theory according to Ritzer and Stepnisky (2014) and Charles (2005) hold that when individuals are faced with strain in the society they resort to any or combination of these five modes of adaptation to cushion the effects:

i. Conformity - Acceptance of cultural goals and pursuing them through socially approved means.

ii. Innovation - Acceptance of cultural goals but rejection of the socially approved means i.e. using unconventional means to obtaining culturally approved goals.

iii. Ritualsim- Rejection of cultural goals but the routinized acceptance of approved means to achieve less elusive or more modest goals.

iv. Retrearism- Rejection of both cultural goals and approved means of obtaining them.

v. Rebellion- Rejection of both cultural goals and approved means of achieving them, while actively attempting to replace both with different goals and means.

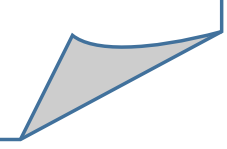

Applying Merton's theory to the major thrust of this paper, it is easy to see that structural strain such as economic recession propels individuals to innovate and adopt unconventional means of achieving societal cherished goals like financial security or success. It is the argument in the paper therefore that investing in Ponzi schemes is one of such possible strategies some Nigerians have devised to cope with the difficulties of meeting their financial obligations in the face of limited legitimate means of achieving them occasioned by recession induced job losses, increasing cost of living and hardships. 
Therefore, strain theory is considered to be a suitable analytical framework for this paper as it provides a succinct explanation to the proliferation of Ponzi schemes and why many Nigerians still invest or patronize them despite their inherent risks.

\section{Methodology}

The paper relied on both secondary and primary sources of data. Journal articles, text books, magazines, newspapers and internet publications were used to source for secondary data. A pre-coded fixed choice questionnaire administered to 56, 34, and 45 Ponzi scheme investors in Port Harcourt (Rivers State), Yenagoa (Bayelsa state) and Awka (Anambra state) respectively provided the primary data since a sample frame for Ponzi schemes investors is non-existent for the researchers to derive a sample size. The study adopted the non-probability sampling procedure based on the fact that only those participating in Ponzi schemes were deemed fit to be part of the study and the researchers were able to identify 135 Ponzi investors who obliged to participate in the study. In doing this, respondents were purposively selected for the study using the snow-balling sampling technique. This involves the identification of a respondent participating in a Ponzi scheme who then refers the researchers to other Ponzi investors. Data generated from pre-coded and fixed choice questions were edited, cleaned, entered and analyzed using MS Excel and the Statistical Package for Social Sciences (SPSS). A descriptive analysis of data was undertaken using tables, charts and graphs, while the chi-square $\left(X^{2}\right)$ inferential statistics was used to test the hypothesis. Ethical considerations were emphasized with informed and voluntary consent as well as the assurance of anonymity and confidentiality of participants.

\section{Findings and Discussions}

The discussion of findings is presented according to the objectives as highlighted in the introductory section of the paper.

The socio-demographic characteristics as shown in Table 1 indicate that 72 $(53.3 \%)$ of the respondents were males while 63 (46.7\%) were females. This indicates that both men and women are actively participating in Ponzi schemes. 
Socio-Demographic Characteristics of the Respondents

Table 1: Distribution of the Socio-Demographic Characteristics of the Respondents

\begin{tabular}{|llc|c|}
\hline Variables & Response Categories & $\mathrm{n}=135$ & $\%=100.0$ \\
\hline Agender & Male & 72 & 53.3 \\
& Female & 63 & 46.7 \\
\hline Age & Less than 20 & 18 & 13.3 \\
& $20-29$ & 80 & 59.3 \\
& $30-39$ & 29 & 21.5 \\
& $40-49$ & 5 & 3.7 \\
& 50 \& Above & 3 & 2.2 \\
\hline Educational Level & Primary & 2 & 1.5 \\
& Secondary & 32 & 23.7 \\
& Tertiary & 95 & 70.4 \\
& Others/Vocational & 6 & 4.4 \\
\hline \multirow{5}{*}{ Occupation } & Civil Service/Private Sector & 21 & 15.6 \\
& Business/Self Employed & 42 & 31.1 \\
& Student & 54 & 40.0 \\
& Unemployed & 18 & 13.3 \\
\hline
\end{tabular}

Source: Fieldwork, 2017

It also revealed that the age bracket 20-29 constitutes the largest $80(59.3 \%)$ category of the respondents, whereas those between 50yrs and above constitutes the least $3(2.2 \%)$, followed by age category $40-49$ with $3.7 \%$. Respondents who were less than 20 years of age made up $13.3 \%$ of the sample while those between the ages of $30-39$ constitute $21.5 \%$. The implication is that younger persons i.e. the youthful participate more in Ponzi schemes than the elderly. This can be partly explained as a result of their exposure to internet facilities and mobile technology as opposed to the elderly who are not so technologically savvy and secondly because of their youthful exuberance and willingness to take more risk.

Furthermore, the educational distribution indicates that $95(70.4 \%)$ of the respondents have attained tertiary education or are in a tertiary institution of learning both at the undergraduate and postgraduate level. Also $23.7 \%$ have secondary education, while $6(4.4 \%)$ were into vocational training and just $2(1.5 \%)$ respondents had primary education. This implies that one's level of education is not a determinant factor for one to participate in a Ponzi scheme as both the highly and poorly educated participate in them. Lastly the occupational distribution of the respondents show that students especially undergraduates and postgraduates constitute the largest participants in the scheme. This can be explained by their active participation in social media platforms where these Ponzi schemes thrive when compared to business people or full time workers who may have less time to spend on the internet and social media. The data also show that $31.1 \%$ are business owners or self-employed, $15.6 \%$ are employed in the civil service or private sector and $13.3 \%$ were unemployed. 


\section{Examining Ponzi Schemes in Nigeria}

The findings from the study show that there is no clear record of the origin of Ponzi schemes in Nigeria. Ndukwe (2016) however asserts that Ponzi schemes are not new in Nigeria and noted the earlier existence of schemes such as "Pyramid" and "Green World". In addition, other earlier Ponzi schemes include 'Umana-Umana' in Calabar and Port Harcourt in the 1980s, 'Planwell' in Edo state from 1991-1992, as well as 'Nopecsto' in Lagos state from 20022007 (Business Post, 2017). Juxtaposing these with the contemporary schemes, Ndukwe argued that their popularity or reach were insignificant when compared to the rush and affinity for the present schemes as evidenced by the number of investors and passion exhibited by their participants.

\begin{tabular}{|l|}
\hline Table 2: Modus Operandi of Ponzi Schemes in Nigeria \\
\hline Step 1: Persuade some few investors to put in money into the investment \\
platform. \\
Step 2: Investors receive initial investment money at a specified interest rate after \\
a specified period of time. \\
Step 3: Coax new and earlier investors based on the initial success to reinvest \\
more money into the system for higher returns. Typically, most of the earlier \\
investors will reinvest. \\
Step 4: Repeat steps 1 through 3 a number of times. During step 2 at one of the \\
cycles, break the chain. Instead of returning the investment money and paying the \\
promised return, escape with the money and start with the process all over again. \\
\hline
\end{tabular}

Source: Compiled by the Authors

Findings from the study indicates that Ponzi schemes took Nigeria by storm with the highest magnitude ever in January 2016 when MMM launched its activities in the country and solicited for potential investors to put in their spare monies for a $30 \%$ return on investment and a $10 \%$ referral bonus. Barely 18 months after the launch of MMM there are over 160 Ponzi schemes operating in Nigeria (see Table 3). Most of the newer POST MMM schemes promised investors outrageous higher returns that ranges from $50 \%$ to over $300 \%$ depending on the investors' ability to get more referrals into the system. This is based on a $1 \times 2$ to $1 \times 5$ matrix, with generational earnings ranging from first to fifth generation as the case may be (see Figure 1). 
Figure 1: Member to Member Donation Matrix
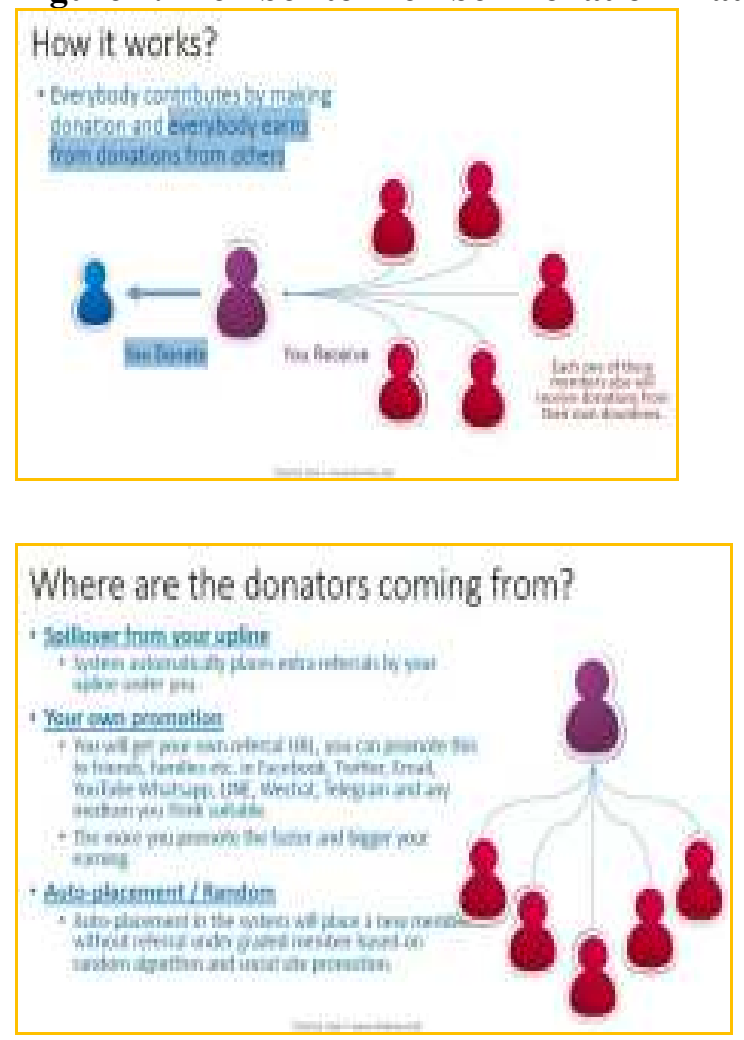

Source: www.icharity.club

Furthermore, in addition to increasing the percentage returns on investment, most of the post MMM Ponzis as part of their marketing strategy to woo potential investors also reduced their withdrawal duration from the usual one month to between two to one week and for some others as short as a day and even within few hours in order to edge out competitors and entice desperate money seekers.

In addition, table 3 displays the identified Ponzi schemes that have existed or in existence in Nigeria. This finding agrees with Onyeji (2016) that different unorthodox financial schemes mostly Mavrodi Mundial Movement (MMM), Ultimate Cycler, Zar Fund, Givers Forum, I-charity, Crowd Rising, Get Help Worldwide, Claritta, Twinkas and so on have continually gained patronage across Nigeria since the recession. It is imperative to note here that the Ponzi schemes identified are by no means exhaustive; as at the time of compilation they were the prevalent ones. However, some of them have collapsed and millions of naira lost, while many more are emerging as the day goes by. More so, we observed that due to the increasing trend in collapse of these Ponzi schemes as evident in inability of investors to access the website and also due to the cost of hosting a website, a new trend appears to be on the rise. This new 
trend is what the authors call the "Donation Groups", where individuals set up peer to peer donation groups modeled after the mainstream Ponzi schemes. These groups are set up on direct message social media platforms such as Whatsapp groups, 2go groups and Blackberry messenger (BBM) and so on. They however seem to be more volatile and dangerous as individuals are added to the group by the admin involuntarily and solicit for donations to other members in order to receive donations in return with varying percentage returns on investment.

\begin{tabular}{|c|c|c|c|}
\hline 1. tetrismart.com & 41. quickmoney.com & 81. smartprimewallet.com & 121. liquidcash.org \\
\hline 2.supercash.com & 42. liftcareer.com & 82. maxclub.org & 122. pondsee.com \\
\hline 3. wexpress.biz & 43. cashblaze.com & 83. getawoof.com & 123. smoothnaira.org \\
\hline 4. nairapropeller.com & 44. loopersclub.com & 84. inspirinig.com & 124. btcinvestment.co.za \\
\hline 5. slimpro-nigeria.net & 45. reeleef.com & 85. quadpay.me & 125. mapurse.com \\
\hline 6. cashcolonyplus.com & 46. goldbox.club & 86. paymenaira.com & 126. cashground.org \\
\hline 7. my.thehelperclub.com & 47. Stablecashout.com & 87. el-earners.com & 127. slickwealth.com \\
\hline 8. 4waycash.com & 48. netelites.org & 88. kingsmen.me & 128. softearner.com \\
\hline 9. donationhub.net & 49. bigbankalert.com & 89. bestpaga.com & 129. quickcharity.com.ng \\
\hline 10. 247 helpers.org & 50. donorhub.net & 90. clockrich.com & 130. 1goalfunding.online \\
\hline 11. paymatch.org & 51. instantfunding.org & 91. royalbills.com & 131. Wellapay.com \\
\hline 12. frezypay.com & 52. bumpercash.com & 92. citifund.org & 132. Doublenaira.org \\
\hline 13. luvwealth.com & 53. unitydonations.com & 93. abcdonor.com & 133. Fastearners.org \\
\hline 14. springcash.com & 54. cashflip.me & 94. clickwealth.com & 134. 1CC Nigeria \\
\hline 15. naijapay.net & 55. steadalert.org & 95. naracle-ng.com & 135.www.eliteclubnet.com \\
\hline 16. doublepay.com & 56. nairatab.net & 96. pearlcashflow.com & 136.Help2get.com \\
\hline 17. btcriver.com & 57. buzzpay.net & 97. cashgram.org & 137.payment paradise.com \\
\hline 18. stablecashout.org & 58. cashex.org & 98.silverpay.com.ng & 138.ultimate cycler.com \\
\hline 19. nairanation.com.ng & 59. clockrich.com & 99. monibucket.com & 139.icharity.com \\
\hline 20. farewealth.com & 60. excelpayer.com & 100. xtrafinance.com & 140.helpers court.com \\
\hline 21. kaynation.com & 61. alwayspays.com & 101. helptobank.com & 141. 21 st century \\
\hline 22. nairaxpress.com & 62. squarepay.org & 102. blonzap.com & 142. Naira cash.com \\
\hline 23. cashnaira.org & 63. tmtcash.co & 103. cashbearer.net & 143. Smile2charity.com \\
\hline 24. cash4cash.net & 64. wealthconnect.ng & 104. popcash.com.ng & 144. Giftcycler.com \\
\hline 25. claritta.com & 65. pekunias.org & 105. nairaguru.com & 145. greenspeer.com \\
\hline 26. bigbankalert.com & 66.looseallomoni.com & 106. cashgivers.com & 146. crystal reward \\
\hline 27. tripleit.com & 67. slypay.org & 107. cashin 3 .club & 147.twinkas.com \\
\hline 28. moniebox.me & 68. bitmoner.io & 108. gainmore.net & 148. mmm-nigeria.net \\
\hline 29. deinvestors.com & 69.redemptioncash.com & 109. cipxwealth.com & 149. thebillioncoin.org.ng \\
\hline 30. paymatch.com & 70. nairadrift.com & 110. sharppayout.com & 150 zarfund.com \\
\hline 31. makenaira.com & 71. nairarush.net & 111. 3xcash.club & 151 giversforum.net \\
\hline 32. doublecash.me & 72. cashreloaded.com & 112. wealthpump.org & 152 gethelpworldwide.com \\
\hline 33. thriftonweb.com & 73. fishers.com & 113. spreadcash.net & 153 crowdrising.net \\
\hline 34. paycycler.com & 74. penihub.com & 114. growtogrow.com & 154 globalcashnigeria.com \\
\hline 35. fundniche.com & 75. safewealth.com & 115. betapay.com.ng & 155 paradisepaymentnigeria.net \\
\hline 36. divinetfund.com & 76. theachievas.com & 116. fastearners.org & 156 joyfuldonor.org \\
\hline 37. paydonor.com & 77. paywellclub.org & 117. switpay.com & 157 nnn-office.com \\
\hline 38. ogive.com & 78. wealthhelpers.com & 118. iniroots.com & 158 passivetreasure.com \\
\hline 39. somapay.com & 79. goldpayng.com & 119. granddonation. net & 159 loopersclub.com \\
\hline 40. moneybox.com & 80. easyblazing.org & 120. peercycler.net & 160 helpbuddy.org \\
\hline
\end{tabular}

Source: Compiled by the authors

The dangers in such groups is the ease at which individual investors can be removed from the group or the group itself can be deleted by the admin after receiving donations from unsuspecting donors since there are no terms of agreement nor digitized donation matrix placements as obtainable in the website based schemes. 


\section{Ponzi Schemes as Coping Strategy to Economic Recession in Nigeria}

In ascertaining if Ponzi schemes are coping strategy to economic recession in Nigeria, the schemes that are most popular among the respondents were investigated. The finding as shown in figure 2 indicates that $30 \%$ posited it was MMM as they affirmed to have invested in it. The second most popular scheme is Twinkas with $19 \%$, followed by Ultimate cycler (18\%), Givers Forum (9\%), I-Charity (7\%), Get Help World Wide (4.1\%), Clarrita (4\%), Smile2Charity (3\%), Help2Get (2\%) and just $1 \%$ invested in Donation Hub. It was also discovered that all the respondents have participated in more than one Ponzi schemes. This is partly as a result of the referral bonuses attached to the schemes and the drive to recruit new investors to get paid and the need to diversify the Ponzi portfolio for increased income.

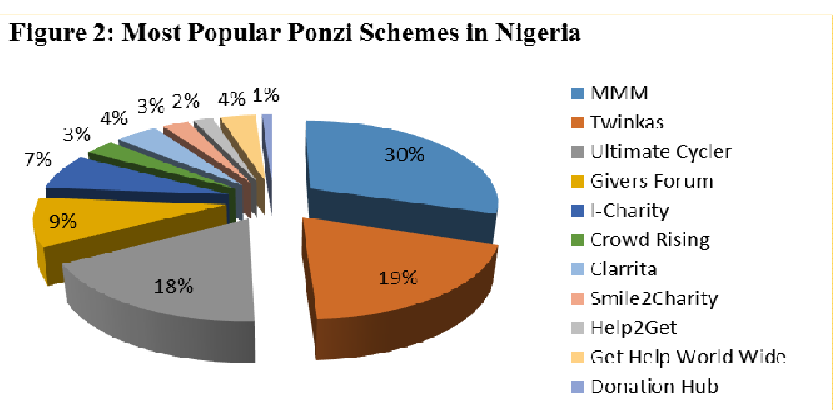

Source: Fieldwork, 2017. Computed on SPSS and MS EXCEL

Secondly, respondents' source of knowledge about Ponzi schemes was investigated and findings in figure 3 reveals that a larger number $65.20 \%$ of respondents knew about Ponzi investment platforms through friends, family members and acquaintances. A further probing reveals that this is as a result of firstly pressure put on investors to recruit new investors into the platform for them to complete their matrix to get paid and secondly the referral bonus provided by the schemer when one refers a new member to join the community. Hence word of mouth from friends, colleagues and family members became a veritable networking and advertising tool for recruiting new members based on mutual trust between the recruiter and potential investor. Another most popular source of information was found to be the internet as $28.90 \%$ affirmed to know about the several schemes on the social media. The internet has been awashed with Ponzi scheme campaigns as aggressive marketing is observed on Facebook, twitter, WhatsApp, blackberry messenger and the likes. The least popular source of Ponzi education is the Television/Radio (3\%), Print Media (0.70\%) and Ponzi campaign invasion in churches $(2.20 \%)$, which appears to be an unusual but however regarded as interesting trend. 


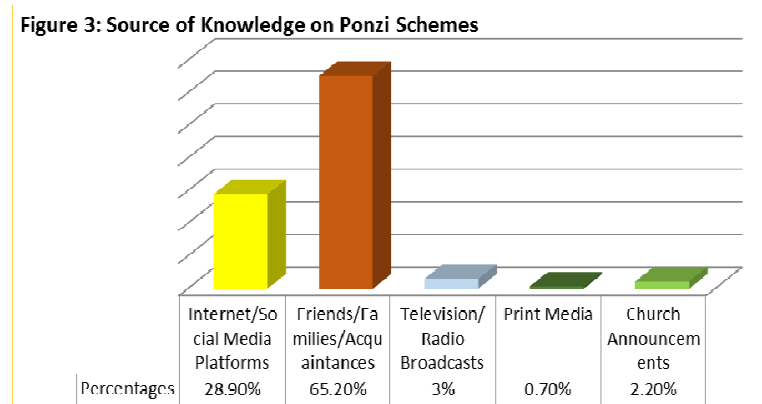

Source: Fieldwork, 2017. Computed on SPSS and MS EXCEL

Thirdly, investigation into the reasons why Nigerians invest in Ponzi schemes was ascertained and findings as shown in figure 4 indicates that majority $(60.3 \%)$ of the respondents attributed it to the current economic conditions associated with the recession. In addition, $19.3 \%$ affirmed that they participate in Ponzi schemes due to the quick turn over on investment within a short period of time. Also, whereas $10.1 \%$ said they invest as a means of diversifying their streams of income, $8.1 \%, 1.5 \%$ and $0.7 \%$ reported they participated in Ponzi schemes due to poverty, inadequate interests on bank deposits and greed to get-rich-quick respectively. The foregoing findings suggests that participation in Ponzi schemes are therefore means through which respondents seek to meet their financial needs so as to be able to cope with the hardship associated with the economic recession. Our findings that Ponzi schemes are thriving as a result of harsh economic realities in the country corroborates that of Asogwa et al. (2017) where they submitted that the Nigerian economy as currently constituted is not viable and as hunger, poverty and unemployment continue to rake the nation, people seek alternative means to cushion the effects.

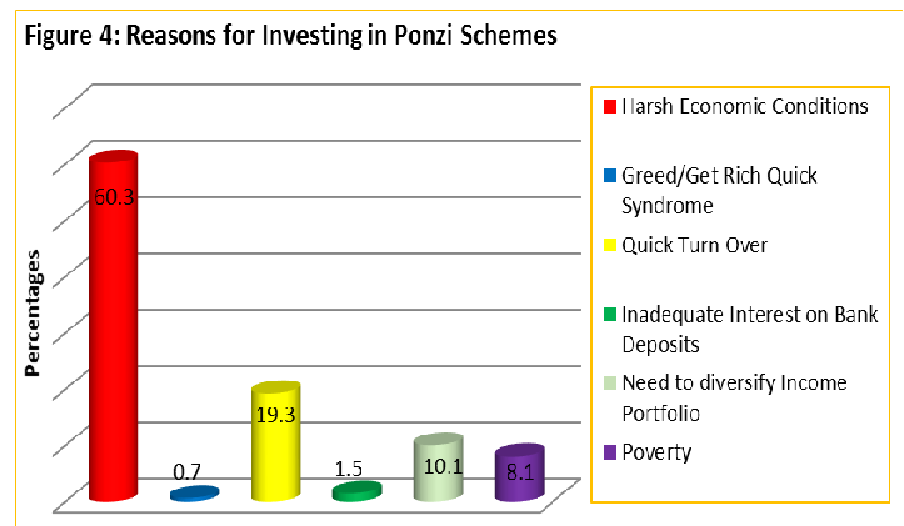

Source: Fieldwork, 2017. Computed on SPSS and MS EXCEL 
In furtherance, inquiry into whether participation in Ponzi schemes is a means of coping with the economic recession, the findings as shown in figure 5 revealed that while $30.40 \%$ of the respondents strongly agree that participation in Ponzi scheme is a means of coping with the economic recession, 37\% agreed to same assertion, and $17.80 \%$ remained neutral. However, $10.40 \%$ of the respondents disagreed while $4.40 \%$ of the respondents strongly disagreed to the assertion that participation in Ponzi scheme is a means of coping with economic recession. The findings therefore suggests that Nigerians participate in Ponzi schemes as a means of meeting their financial needs which has been constrained by the structural strain associated with the economic recession in the country.

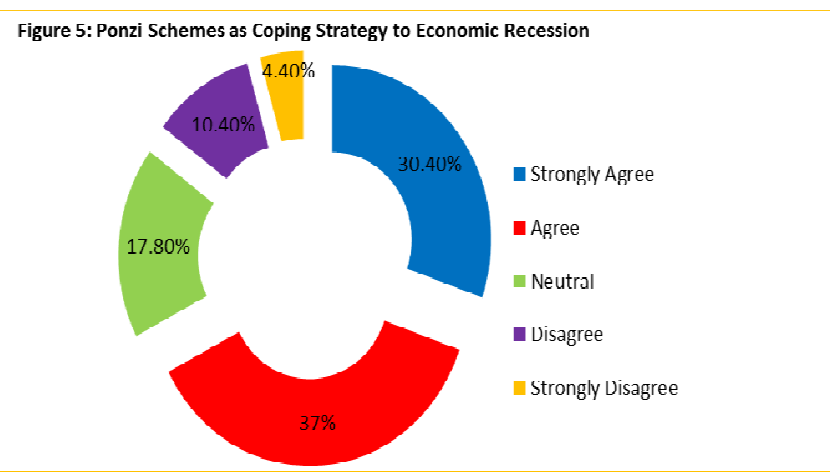

Source: Fieldwork, 2017. Computed on SPSS and MS EXCEL

In view of the foregoing, a separate study by Bupo and Abam-Smith (2017) corroborates our findings that Ponzi schemes legitimately increased income of participants and reduces the impact of recession on them. To this end, the paper submits that Ponzi scheme is one of the means by which Nigerians cope with the hardship associated with economic recession; hence the proliferation of these schemes since early 2016 when the nation's economy slipped into recession is not mere coincidence.

\section{Test of Hypothesis}

In order to test the significance of the responses to the assertion that Ponzi schemes are a coping strategy for economic recession, the chi-square $\left(X^{2}\right)$ inferential statistics was used to test this relationship. The test was run at the 0.05 level of significance using the SPSS (Version 20).

\section{Ho: Investing in Ponzi schemes is not a coping strategy for economic recession in Nigeria}


Table 4: Hypothesis Test Summary

\begin{tabular}{|c|c|c|c|}
\hline Null Hypothesis & Test & Sig. & Decision \\
\hline $\begin{array}{l}\text { The categories of Ponzi } \\
\text { Schemes is not a coping } \\
\text { strategy to economic } \\
\text { recession in Nigeria occur } \\
\text { with equal probabilities }\end{array}$ & $\begin{array}{l}\text { One-Sample } \\
\text { Chi-Square } \\
\text { Test }\end{array}$ & .000 & $\begin{array}{l}\text { Reject the null } \\
\text { hypothesis }\end{array}$ \\
\hline
\end{tabular}

Asymptotic significances are displayed. The significance level is .05 (SPSS Output)

The $\chi 2$ result indicates an alpha value (p) of .000 . This implies that $\mathrm{p} .000<$ .05 , hence our decision rule is that we reject the null hypothesis and accept the alternate hypothesis. This implies that participation in Ponzi schemes is a means of coping with the economic recession in Nigeria.

Lastly, an inquiry into the perceptions of the respondents' on whether Ponzi schemes are effective and reliable coping strategies was conducted. Findings as shown in figure 6 indicate that $50 \%$ of the respondents posit that Ponzis are unreliable and but they are effective. A further probe reveals that they were unreliable because there are neither warranties nor insurances.

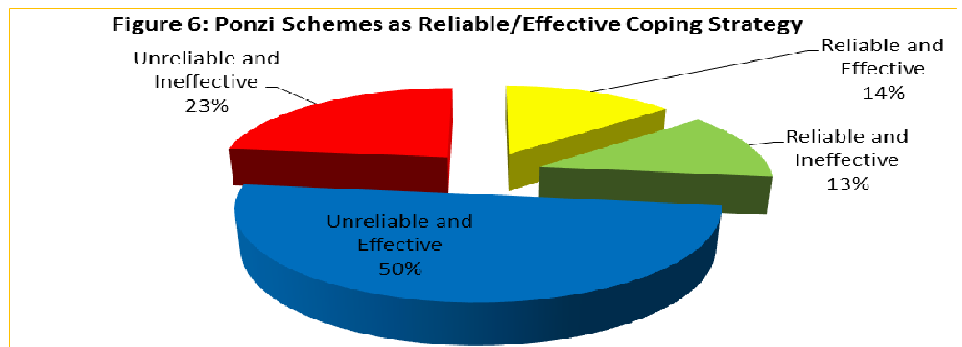

Source: Fieldwork, 2017. Computed on SPSS and MS EXCEL

This implies that the risks are very high as investors are not fully sure of retrieving their investments due to the volatile nature of the schemes either by means of collapsing or regular website upgrade or total crash with no one to be held liable in cases of financial loses. On the other hand, it is effective because the turnover is huge and fast as indicated by most respondents who have been making huge profits from the schemes. Furthermore, whereas $23 \%$ claim that Ponzi schemes are both unreliable and ineffective, $14 \%$ asserted that they are reliable and effective; while just $13 \%$ were of the view that Ponzi schemes are reliable and ineffective. This position is also corroborated by the study of Bupo and Abam-Smith (2017) where they reported that participants perceive Ponzi schemes to be scams and non-durable due to the fact they these schemes are sustained by continuous admission of new investors, hence its vulnerability to abrupt collapse. This implies that despite knowing the implications, many involve in Ponzi schemes as a strategy of cushioning the effects of harsh economic realities. 


\section{Conclusion}

Drawing from the findings of this study, it has been established that there is a proliferation and prevalence of Ponzi schemes in Nigeria and the wide acceptance or patronage has been attributed to the economic recession in the country. In view of the foregoing, we therefore submit that periods of economic distress presents practical conditions of socio-economic strains for a large number of people who become susceptible to fraudulent investments proposals such as the Ponzi schemes in a bid to cope with associated hardships. In the light of the foregoing, the paper concludes that investments in Ponzi schemes are innovative strategies of coping with the strain or harsh economic realities that many experience as the nation failed to provide adequate and realistic means of achieving culturally valued goals of financial security and comfortable standard of living. Hence, until the present economic downturn is adequately addressed or palliatives provided for Nigerians, Ponzi schemes would continue to thrive with its attendant effects.

\section{Recommendations}

The following recommendations are therefore made for policy and implementation:

1. Government should revamp the economy through effective economic diversification policies that will enhance provision of socio-economic livelihood like jobs, social security and welfare packages as palliatives to recession induced strain.

2. The EFCC and ICPC should institute economic cyber security experts that would clamp down suspected fraudulent Ponzi schemes and apprehend the schemers or operators.

3. The government and other stakeholders in the financial industry should adequately untilize the electronic and social media platforms to sensitize the citizenry, especially the youth on the dangers of investing in Ponzi schemes.

4. There should be upward review of the minimum wage as recession induced inflation and rising cost of living predisposes individuals to innovate illegitimate coping means as palliatives to recession induced strain.

\section{References}

Adepoju, P. (2016) The meteoric rise of one of the world's largest Ponzi schemes in Nigeria. CNN. Retrieved 17th May 2017, from http://edition .cnn.com/2016/12/14/africa/mmm-ponzi-scheme-nigeria/.

Akhaine, S. (2017) Nigerians lost N18 billion to Ponzi scheme operators, says NDIC. The Guardian. Retrieved 6th April, 2017, from https://guardian. ng/news/nigerians-lost-n18-billion-to-ponzi-scheme-operators-says-ndic/.

Asogwa, I.E., Etim, E.O., Etukafia, N.I., Akpanuko, E.E. \& Ntiedo, B.E. (2017) Synopsis of Nigerian economy and the growth of Ponzi schemes. Global Journal of Management \& Business Research: (B) Economics \& Commerce, 17(3): 45-54. 
Blanton, K. (2012) The rise of financial fraud: Scams never change, but disguises do. Financial Security Project, pp.1-12.

Bupo, G.O. \& Abam-Smith, I. (2017) Business education students' perception of the durability and importance of online Ponzi schemes. Rivers Business Education Journal (RIVBEJ), 2(1): 260-269.

Business Post (2017) History of Ponzi schemes. Retrieved 17th May 2017, from https://www.thebusinesspost.ng/tms/mmm-disaster-waiting-happen/history-ponzi-schemes-nigeria.

Central Bank of Nigeria (2015) Statistical Bulletin.

Charles, J.O. (2005) Sociological theory: A historic-analytical approach on man and society. Lagos: Serenity.

Deason, S., Rajgopal, S., Waymire, G. \& White, R. (2015) Who Gets Swindled in Ponzi Schemes? Atlanta, G.A: Goizueta Business School Pub.

Elezuo, E. (2016) The rise and 'crash' of MMM Nigeria. Retrieved 28th April, 2017, from http://thebossnewspapers.com/the-rise-and-crash-of-mmm-nigeria/.

Ewubare, K. (2017) MMM participant commits suicide in Nsukka. Retrieved 2nd May, 2017, from https://gossip.naij.com/1104793-olajumoke-coldsouth-africa-thought-put-ac-photo-video.html.

Folkman, S., Lazarus, R.S., Dunkel-Schetter, C., Delongis, A. \& Gruen, R.J. (1986) Dynamics of a stressful encounter: Cognitive appraisal, coping, and encounter outcomes. Journal of Personality and Social Psychology, 50(5): 996-1003.

Greenspan, S. (2011) Fooled by Ponzi (and Madoff): How Bernard Madoff made off with my money. Westport, CT: Praeger. www.stephengreenspan.com.

International Monetary Fund (2016) Online databank. Retrieved 3rd May, 2017, from www.imf.org.

Johnston, K.C., Johnson, K.M. \& Hummel, J.A. (2010) Ponzi schemes and litigation risks: What every financial services company should know. DOCX 4/20/20109:32:03AM.

Merton, R. (1938) Social structure and anomie. American Sociological Review, 3(5): 672-682, Doi:10.2307/2084686.

Nash, R.M. (2013) Trusting the con man: The role of social networks in the diffusion of fraud. Dissertation Submitted to the School of Criminology, Faculty of Arts and Social Sciences, Simon Fraser University.

National Bureau of Economic Research (2007) Business Cycle Expansions and Contractions.

National Bureau of Statistics (NBS) (2016) Unemployment rate in Nigeria. Retrieved 1st May, 2017, from www.nigerianstat.gov.ng.

Ndukwe, E. (2016) The rise of Ponzi schemes in Nigeria: The pros and cons. Retrieved 10th May, 2017, from http://www.etechgist.com/2016/12/the-riseof-ponzi-schemes-in-nigeria.html. 
NOIPolls (2017) Multi-level marketing and ponzi schemes used to cushion the effect of economic downturn. Retrieved 6th May, 2017, from http://Ponzischeme-Survey-in-Nigeria-1.htm.

Noko, E. (2016) Economic recession in Nigeria: Causes and solution. Retrieved 28th March 2017, from http://educacinfo.com/economicrecession-nigeria/.

NTA (2016, December 18th) NNN Nigeria: The rise of Ponzi empires. Retrieved 30th April, 2017, from http://www.nta.ng/news/domestic/20161218-nnn-nigeria-rise-ponzi-empires/.

Odunsi, W. (2017, April 7th) MMM agents arraigned for fraud. Retrieved 17th May, 2017, from http://dailypost.ng/2017/04/07/mmm-agents-arraignedfraud/.

Onuchuku, O. (2016) War of supremacy between unemployment and inflation in Nigeria: Who is the actual loser? An Inaugural Lecture Delivered at the University of Port Harcourt. Series No. 133; University of Port Harcourt Press Ltd. ISSN: 1119-9849.

Onyeji, E. (2016, December 16th) 7 trending Ponzi schemes in Nigeria in 2016. Agency Report.

Opejobi, S. (2017, February 28th) MMM: UNIOSUN to expel 4,000 students for investing in Ponzi scheme. Retrieved March 22nd, 2017, from http://dailypost.ng/2017/02/28/mmm-uniosun-expel-4000-students-investing-ponzi-scheme/.

Premium Times (2017, May 15th) Despite losing billions to MMM, Nigerians throng another Ponzi scheme - Twinkas. Retrieved May 30th, 2017, from http://www.premiumtimesng.com/news/top-news/225271-despite-losingbillions-mmm-nigerians-throng-another-ponzi-scheme-twinkas. html.

Punch (2016, December 12th) Nigerians are patronising Ponzi schemes because of recession. The Boss Newspaper. Retrieved 19th May, 2017, from http://punchng.com/nigerians-patronising-ponzi-schemes-recession/.

Quisenberry, W.L. (2017) Ponzi of all Ponzis: Critical analysis of the Bernie Madoff scheme. International Journal of Econometrics \& Financial Management, 5(1): 1-6.

Ritzer, G. \& Stepnisky, J. (2014) Sociological theory. (9th ed.). Singapore: McGraw-Hill.

Rodney, S. (2010) America's housing and financial frauds (2 ${ }^{\text {nd }}$ ed.). New York: Silverpeak Enterprises.

Sadiraj, K. \& Schram, A. (2000) Informed and uninformed investors in an experimental Ponzi scheme. JEL classification, 92(73): 1-20.

Securities \& Exchange Commission (SEC, 2009). SEC charges R. Allen Stanford: Stanford international bank for multi-billion dollar investment scheme. Retrieved 17th February, 2017, from http://www.sec.gov/news/press/2009/2009-26.htm.

Sher, Y. (2015) Branding in ponzi investment schemes. Thesis Submitted to Vega School of Brand Leadership, Johannesburg, South Africa. 
Stelter, D., Berger, R., Odewald, J. \& Schilder, D. (2013) Collateral damage: Ending the era of ponzi finance. Boston: The Boston Consulting Group.

Tayo, A.O. (2016) MMM Nigeria: The dark history of this popular Ponzi scheme. Pulse Nigeria. Retrieved 8th May, 2017, from http://pulse.ng/gist/mmm-nigeria-the-dark-history-of-this-popular-ponzi-scheme-id5523761.html.

Wilkins, A.M., Acuff, W.W. \& Hermanson, D.R. (2012) Understanding a Ponzi scheme: Victims' perspectives. Journal of Forensic \& Investigative Accounting, 4(1): 1-19.

Wisner, B., Blaikie, P., Cannon, T. \& Davis, I. (2004) At risk: Natural hazards, people's vulnerability and disasters. (2nd ed.). NY: McGrawhill. 